\title{
EFEKTIVITAS TEMPAT PENYIMPANAN PROTOKOL NOTARIS YANG TELAH BERUMUR 25 TAHUN
}

\author{
Hery Sunaryanto \\ Magister Kenotariatan Universitas Islam Malang \\ Jalan Mayjend Haryono Nomor 193 Malang \\ Email: herysunaryanto@gmail.com
}

\begin{abstract}
Abstrak
Tempat penyimpanan protokol Notaris yang berumur dua puluh lima tahun jo. Pasal 70 huruf e UUJN selama ini tidak berjalan efektif dikarenakan MPD belummempunyai lokasiuntuk menyimpandengan kondisi representatif. Faktor-faktor yang mempengaruhi efektifitas penyimpanan protokol Notaris: pertama, masalah aturan yang ada di UUJN dimana belum ditentukan secara tegas mengenai Jadwal Retensi Arsip, maka perlu dibuatkan aturan baru mengenai masa kadaluarsa di UUJN/UUJN-P atau memakai aturan kadaluarsa yang ada di pasal 1967 KUHPerdata dan Pasal 78 KUHP, kedua, masalah tempat penyimpanan, maka perlu membuat aturan baru mengenai penyimpanan yang lebih modern dan tidak banyak memerlukan tempat dengan menggunakan penyimpanan elektronik/digital.
\end{abstract}

Kata Kunci: efektvitas, protokol notaris, penyimpanan, MPD

\begin{abstract}
The storage area of the twenty-five year old Notary protocol jo. Article 70 letter e UUJN has not been effective so far because the MPD has no location to save it with representative conditions. Factors that influence the effectiveness of storage of the Notary protocol: first, the problem of rules in UUJN where it has not been explicitly stipulated regarding the Archive Retention Schedule, it is necessary to make new rules regarding the expiration date of UUJN / UUJN-P or use the expiration rules in article 1967 Civil Code and Article 78 of the Criminal Code, second, the problem of storage, it is necessary to make new rules regarding storage that are more modern and do not require much space using electronic/ digital storage.
\end{abstract}

Keywords: effectiveness, notary protocol, storage, MPD 


\section{PENDAHULUAN}

Awal mulanya lembaga kenotariatan ada di Indonesia adalah sejak jaman penjajahan kolonial, yang timbul karena dari semakin banyaknya orang-orang bangsa Eeropa dan bangsa timur asing lainnya yang menetap di Indonesia dan dengan semakin majunya perkembangan bisnis di antara mereka makatentunya memerlukan suatu kepastian hukum di dalam melakukan perjanjian-perjanjian bisnis di antara mereka.

Notaris itu adalah pejabat publik, yang bisa diartikan bahwaorang yang telah ditetapkan dengan SK. Menteri Hukum dan HAM sebagai pejabat umum, dan diberikankewenangan sekaligussuatu kewajiban dari negara untuk melayani kebutuhan masyarakat dalam yang berkaitan dengan pembuatan akta perjanjian dan lainnya sesuai peraturan perundangundangan. Dalam menjalankan tugas melayani kebutuhan warga dalam bidang hukum, untuk memberikan suatu bentuk proteksi dan garansi agar dapat tercapaisuatu ketegasan hukum tetapi mereka tidak digaji oleh pemerintah. Disebutkan juga bahwa Notaris adalah pejabat umum yang merupakan kepanjangan tangan dari pemerintah yang memiliki wewenang dan bertugas memberikan pelayanan kepada masyarakat di bidang keperdataan dalam pembuatan akta-akta otentik. Di dalam Pasal 1 UUJNPdi disebutkan pula bahwa Notaris adalah pejabat umum yang berwenang untuk membuat akta otentik dan kewenangan lainnya sebagaimana dimaksud dalam Undang Undang ini atau berdasarkan undang-undang lainnya. Akta notaris adalah akta otentik karena bersifat terkuat dan terpenuh sehingga dapat menjamin kekuatan hukum atas akta tersebut.

Dalam menjalankan tugasnya melayaniwargamembuat akta autenticnotaris juga memiliki kewajiban untuk menyimpan, melakukan tugas pelaporan dan pengarsipan dokumen-dokumen yang berhubungan dengan pekerjaannya yang disebut protokol notaris, yaitu minuta akta, daftar akta yang telah dikeluarkan, daftar legalisasi surat-surat dibawah tangan, daftar surat dibawah tangan yang dibukukan, daftar klapper, daftar surat wasiat, dan lain-lain yang berhubungan dengan pekerjaannya. Protokol notaris tersebut merupakan dokumen-dokumen penting yang termasuk arsip negara yang harus dijaga keasliannya dan dipelihara dari kerusakan atau kehilangan karena sewaktu-waktu jika diperlukan oleh penghadap atau ahli warisnyauntuk hal-hal yang mungkin terjadi di waktu yang akan datang untuk suatu pembuktian. Pada Pasal 1 angka 13 UUJN definisi dari protokol/arsip penting notaris bisa diartikan sebagaisuatu bundel berkas pentingmilik negara yang wajib dilindungi, disimpan, dijaga dan dirawat oleh Notaris menurut aturan yang ada di undang-undang. Sebagai salah satu dari arsip atau dokumen penting milik negara makasudah menjadi 
kewajiban bagi notaris, notaris pengganti, notaris pemegang protokoldan MPD menjaga, merawat dan menyimpan dokumen tersebut dalam keadaan atau kondisi bagaimanapunjuga meski notaris si pemilik protokol tengah cuti atau/bahkan telah meninggal dunia.

Dengan adanyaperubahan jaman yang semakin maju dan canggih, meledaknya jumlah penduduk dunia dan meningkatnya perekonomian masyarakat pada akhir-akhir ini tentunya kebutuhan akan perlindungan dan kepastian hukum bagi masyarakat dalam kegiatanbermasyarakat dan berbisnis sehari-hari menyebabkan kebutuhan akan jasa notaris semakin berkembang dan semakin kompleks demi melayani masyarakat tersebut. Hal ini tentunyapada suatu saat akan membutuhkan suatu tempat untuk penyimpanan protokol notaris yang memadai aman, efektif, efisien dan tidak banyak memerlukan tempat.

Perihal dengan penyerahan protokol notaris diatur dalam Pasal 62, Pasal 63, Pasal 64 dan juga di Pasal 65 UUJN. Menurut Pasal 63 ayat (2) UUJN yang isinya antara lain menyebutkan bahwa penyerahan dokumen penting notaris dilakukan paling lambat 30 hari dengan membuat berita acara penyerahan. Pasal 63 ayat (3) menyebutkan bahwa penyerahan tersebut dilaksanakan notaris atau ahli warisnya kepada notaris lainnya yang ditunjuk MPD. Pasal 63 ayat (5) isinya antara lain menyebutkan bahwa dokumen penting notaris yang telah berusia minimal dua puluh lima tahun diserahterimakan oleh notaris yang menerima protokoldari notaris lain kepada MPD. Sedangkan di dalam Pasal 70 huruf e UUJN mengatur tentang kewenangan MPD untuk menetapkan lokasimenyimpan kumpulan dokumen penting notaris yang waktudiserahterimakansudah berusia minimal dua puluh limatahun atau seperempat abad.

Penyimpanan arsip penting negara (kumpulan dokumen penting notaris), tentunya harus selalu memperhatikan faktor keamanan protokol tersebut dari resiko kerusakan, dengan cara seksama dan penuh kehatihatian perlu dijaga agartidak rusak, sobek, tercecer, rusak karena usia atau dimakan serangga, atau bahkan hilang. Menjadi kewajibanbagi pejabat umum (notaris) setelah ituadalah menyimpan protokol tersebutdan setelah pensiun diserahkan ke Notaris penerima Protokol yang ditunjuk oleh MPD, dan untuk protokol yang minimal sudah berusia dua puluh lima tahun diserahkan ke MPD untuk disimpan. Kewajibanlainnya ialah melaporkan setiap bulan sekali daftarsemua kegiatan terkait dengan tugas dan kewenangannya kepadaMajelis Pengawas di wilayah kerjanya masingmasing, sedangkan mengenai tugasnya terkaitdengan pembuatan wasiat melapor ke pusat wasiat Kementrian Hukum dan HAM.

Kegiatan penulisan yang banyak dan terus menerus tentu mengakibatkan masalah tersendiri bagi Notaris dalam hal perawatan dan 
menyimpan arsip tersebut. Jangka waktu menyimpan yang lama dalam perjalanannya tentu akan ditemukan banyak resiko, diantaranya adalah resiko kerusakan karena usia atau dimakan serangga, sobek, tercecer atau bahkan hilang.

Berdasarkan uraian latar belakang tersebut permasalahan yang akan dibahas, yakni bagaimanakah efektifitas tempat penyimpanan protokoll yang minimal sudah berusia dua puluh lima tahun jo. pasal70 huruf e UUJN? faktor-faktor penyebab tidak efektifnya tempat penyimpanan protokol notaris yang sudah berusia dua puluh lima tahun atau lebih dan upaya penyelesaiannya?

\section{METODE PENELITIAN}

Metodologi menurut artinya dalam Bahasa Indonesia ialahsuatu cara yang sistematis dipergunakan dalam melakukan suatu pekerjaan agar dapat dicapai sesuai dengan target yang ditentukan; cara kerja yang sitematis untuk mempermudah pelaksanaan kegiatan agar bisa mencapai target yang ditetapkan di awal. ${ }^{1}$ Sedangkan arti dari penelitian adalah suatu bentuk kegiatan yang dilakukan sistematis menurut metodologi yang ilmiah dalam usahanya memecahkan suatu permasalahan di masyarakat. ${ }^{2}$ Metode penelitian hukum ialah suatu ilmu mengenaitata cara dalam melaksanakan penelitian hukum dengan sistematis. ${ }^{3}$ Sedangkan jenis penelitian yang dipergunakan oleh penulis dalam penelitian ini ialah penelitian deskriptif yaitu penelitian yang bertujuan untuk melukiskan sesuatu hal didaerah tertentu dan pada saat-saat tertentu. ${ }^{4}$ Di dalam penelitian hukum deskriptif mempunyai sifat memaparkan dan mempunyai tujuan untuk mendapatkan gambaran secara terinci tentang kondisi hukum yang diberlakukan di suatu tempat pada saat tertentu, atau mengenai gejala yuridis yang ada, atau peristiwa hukum tertentu pula yang terjadi dalam masyarakat. ${ }^{5}$

Penulis dalam hal ini mempergunakan metode penelitian hukum yang bersifat empiris, yaitu istilah lain dari penelitian hukum yang bersifat sosiologis yangbisa juga dikatakan penelitian langsung/lapangan yaitu suatu

${ }^{1}$ Pranala (link):https://kbbi.web.id/metode, diakses tanggal 12 November 2018 pukul 15.00 WIB

${ }^{2}$ Sukandarrumidi, Metode Penelitian: Petunjuk Praktis untuk Penelitian Pemula, (Yogyakarta; Gajah Mada University Press, 2006), hal. 111.

${ }^{3}$ Abdulkadir Muhammad, Hukum dan Penelitian Hukum, (Bandung: Citra Aditya Bakti, 2004), hal.57

${ }^{4}$ Suratman dan Philips Dillah, Metode penelitian Hukum, (Bandung: Alfabeta, 2015), hal..47.

${ }^{5}$ Abdulkadir Muhammad, Op.Cit. hal. 50. 
penelitian yang berasal dari data yang diperoleh langsung dari sumbernya yaitu masyarakat dengan melakukan penelitian lapangan ${ }^{6}$.

Dalam penelitian ini penulis menggunakan tehnik "purposive sampling" yaitu memilih sebagian dari populasi yang sekiranya dapat mewakili dari keseluruhan obyek penelitian ini. Adapaun teknik memilih sebagian kecil dari keseluruhan obyek penelitian yang biasa disebut dengan teknik sampling.

Adapun yang menjadi sumber datanya yaitu: a) Kelompok Notaris Anggota MPD (Siti Noer Endah, Yudi Ansyah, Dyah Ayu Wisnuwardhani); b) Kelompok Notaris Pemegang Protokol Notaris Lainyang (Dyah Widhiawati, Faisal Abdullah Waber, Ita Kristiana, Sulasiyah Amini). Pengumpulan data primer dilakukan dengan menggunakan beberapa teknik observasi (pengamatan) di lokasi penelitian atau terhadap peristiwa hukum yang menjadi objek kajian dan awancara, yang dilakukan dengan responden. Penulis menggunakan teknik observasi dan wawancara langsung dengan notaris yang juga anggota MPD Kota Malang dan beberapa notaris penyimpan protokol notaris lain. Setelah data penelitian berhasil dikumpulkan baik itu data primer maupun data sekunder selanjutnya dipilah-pilah, diklasifikasi dan kemudian dianalisis.

\section{PEMBAHASAN}

\section{Efektivitas tempat penyimpanan protokol notaris yang sudah berusia 25 tahun jo. pasal 70 huruf e UUJN}

Protokol notaris berupa arsip atau dokumen penting milikNegara yang fungsinya sebagai alat bukti kuat tentunyaharus tetap disimpan, dijaga dan dirawat oleh Notaris.Sebagai alat bukti yang kuat yang bisa memberikan kepastian kepada hakim tentang peristiwa hukum yang telah terjadi dan dinotariilkan. Di dalam Pasal 1 angka 13 UUJN-P menjelaskan tentang protokol notaris itu merupakan sekumpulan arsip/dokumen penting negara yang wajib untuk ditempatkan pada lokasi yang representatif sebagai tempat penyimpanan dan dijaga dari resiko terselip/tercecer, rusak atau bahkan hilang oleh Notaris sesuai amanat undang-undang yang berlaku. Karena hal tersebut maka notaris, notaris pengganti, dan notaris pemegang protokol wajib menyimpan, menjaga dan merawat sebaik-baiknya protokol notaris tersebut, dimanahal tersebut akan tetap berlaku selama jabatan Notaris masih diperlukan. Tetapi untuk penyimpanan protokol yang telah berumuir 25 tahun atau lebih menjadi kewenangan MPD untuk menentukan tempat penyimpanannya.

${ }^{6}$ Ibid. hal.53. 
Menurut pendapat dari Siti Noer Endah, protokol Notaris yang sudah berusia minimal seperempat abad menurut UU memang harus diserahkan ke MPD. Hal ini sesuai dengan Pasal 63 ayat (5) UUJN/UUJN-P yang berbunyi bahwa protokol Notaris dari Notaris lain yang pada waktu penyerahannya berumur 25 (dua puluh lima) tahun atau lebih diserahkan oleh Notaris penerima protokol Notaris kepada Majelis Pengawas Daerah. Namun selama ini pada kenyataannya hal tersebut tidak pernah dilaksanakan. Karena pasal 63 ayat (5) UUJN/UUJN-P tidak dilaksanakan maka Pasal 70 huruf e UUJN otomatis tidak juga bisa dilaksanakan. Hal ini menurut beliau terjadi tidak hanya di Malang saja, bahkan di seluruh Indonesia tidak dijalankan karena tidak punya tempat atau tidak punya kantor. Tetapi meskipun punya kantor hal tersebut tidak bisa terlaksana jika kantornya tidak mampu menampung seluruh protokol notaris yang seharusnya disimpan di kantor MPD. Maka dari itu semenjak MPD terbentuk di kota Malang sampai saat ini dokumen yang sudah berusia seperempat abad tetap ada di kantor notaris pemegang protokol notaris lain. Walaupun kadang notaris penyimpan/pemegang protokol notaris lain juga merasa keberatan karena protokolnya sendiripun juga semakin tahun semakin banyak.

Senada dengan pendapat Stiti Noer Endah, Yudi Ansyah mengatakan bahwa pelaksanaan pasal 63 ayat (5) UUJN/UUJN-P dan pasal 70 huruf "e" UUJN tidak bisa dijalankan karena faktor MPD yang tidak punya kantor dan tempat penyimpanan, sehingga tidak mungkin berkasberkas penting notaris yang minimal sudah berusia seperempat abad tersebut ditempatkan di kantor MPD yang pada kenyataannya selama ini kantor MPD menempati kantor Ketua MPD, sedangkan berkas-berkas protokol notaris dari Ketua MPD yang juga menjabat sebagai Notaris juga sangat banyak. Hal ini tentunya sangat merepotkan bagi MPD, juga merepotkan bagi notaris penyimpan protokol notaris lain bila tidak diserahkan ke MPD. Karena ada beberapa notaris yang menyimpan $3-5$ protokol notaris lain yang jumlahnya sangat banyak yang tentunya membutuhkan tempat yang luas untuk penyimpanannya dan membutuhkan perawatan ekstra agar protokol notaris tersebut tetap awet dan bisa dipergunakan bila sewaktuwaktu ada para pihak atau ahli waris dari penghadap membutuhkan protokol notaris tersebut untuk suatu keperluan yang mendesak. Tentunya hal ini sangat merepotkan bagi notaris-notaris penyimpan protokol notaris lain,karena untuk arsip/dokumen penting-notaris yang usianya sudah seperempat abad tersebut tentu kondisinya sudah lapuk atau banyak yang sudah berubah dibanding sebelumnya.

Sedangkan pendapat dari Diah Ayu Wisnuwardhanibahwa memang ada kendala tempat atau kantor MPD sebagai tempat untuk menyimpan 
arsip/protokolnotaris yang sudah berusia seperempat abadtersebut yang menjadi sebab tidak terlaksananya aturan pasal 63 ayat (5) UUJN/UUJN-P dan pasal 70 huruf "e" UUJN yang saling terkait satu dengan yang lain, karena selama ini MPD Kota Malang tidak memiliki kantor sendiri. Sebenarnya Notaris-notaris di Malang sudah berusaha untuk membeli kantor dengan urunan tetapi belum selesai prosesnya, dan meskipun sudah punya kantor akan tetapi bila untuk menampung arsip/protokolnotaris yang sudah berusia seperempat abad tersebut tentunya juga tak akan bisa menampungnya mengingat kondisi kantor yang tidak memungkinkan.

Notaris Dyah Widhiawati sebagai Notaris pemegang protokol dari Darma Sanjata Sudagung yang telah pensiun, mengatakan bahwa tidak mengetahui mengenai protokol notaris yang sudah berusia seperempat abad tersebut harus diserahkan ke MPD. Dan pada waktu sebelum serah terima protokol notaris dari Notaris Darma Sanjata Sudagung tidak pernah ada sosialisasi dari MPD mengenai hal tersebut. Beliau berpendapat bahwa hal tersebut karena MPD tidak mempunyai tempat penyimpanan yang representatif yang bisa menampung protokol-notaris yang sudah berusia seperempat abad ataulebih sehingga penyimpanan tetap dipegang oleh notaris pemegang protokol.

Notaris Ita Kristianajuga mengatakan hal yang sama, beliau tidak mengetahui bahwa arsip/protokol-notaris yang sudah berusia minimal dua puluh limatahun atau sepermpat abadlebih pada saat serah terima protokol notaris dari Notaris Eko Handoko harus diserahkan ke MPD. Notaris Eko Handoko yang merupakan notaris senior di Kota Malang mempunyai banyak protokol yang sudah berusia dua puluh limatahun atau bahkan lebih, apalagi waktu beliau sewaktu belum pensiun juga pemegang protokol notaris lain sehingga tentu sangat merepotkan bila MPD tidak punya tempat penyimpanan yang memadai.

Notaris senior di Kota Malang yang kebetulan belum pensiun yaitu Notaris Faisal Abdullah Waber mengatakan bahwa beliau selama ini juga kurang perhatian mengenai peraturan tentangmenyerahkan protokol berusia dua puluh limatahun (seperempat abad) lebih tersebut. Beliauberpendapat bahwa peraturan tersebut sangat ribet dan merepotkan notaris pemegang protokol notaris lain, akan lebih safety bila protokol notaris tersebut tetap disimpan oleh notaris pemegang protokol. Makanya tindakan MPD yang tidak melaksanakan pasal 63 ayat (5) UUJN/UUJN-P dan pasal 70 huruf e UUJN tersebut sangat bisa dimaklumi. Seharusnya MPD yang dibentuk oleh KemenKumHam diberikan tempat atau gedung yang representatif karena tugas MPD sangat vital terutama untuk menyimpan protokol-protokol notaris yang merupaka arsip negara.Tentang hal ini sebenarnya sudah ada di PerMenKum dan HAM No. 40/2015 tentang Majelis Pengawas (susunan 
organisasi, tata cara pengangkatan dan pemberhentian anggota, dan tata kerjanya)pada pasal 18 ayat (5) tetapi masalahnya adalah tempat/ruangan yang tidak representatif.

Notaris Sulasiyah Amini mengatakan bahwa sebetulnya NotarisNotaris penerima protokol dari Notaris lain tersebut tahu bahwa ada aturan tentang penyerahan protokol yang sudah berusia seperempat abadke MPD pada waktu serah terima protokol notaris dari notaris lain lain. Tetapi karena MPD tidak memasalahkan dikarenakan tidak adanya tempat penyimpanan maka hal tersebut tidak dilakukan. Ibu Notaris Sulasiyah Amini ini sebagai notaris beliau juga menyimpan 3 protokol notaris dari notaris lain yang sangat senior di Kota Malang yang sudah pensiun dimana protokolnotaris berusia seperempat abad atau bahkan lebih sangat banyak, dan banyak yang sudah lapuk karena dimakan usia. Dalam suatu kesempatan beliau pernah menyinggung mengenai hal tersebut tetapi tidak ada respon balik dari pengurus MPD maupun dari notaris-notaris lainnya. Padahal beliau sangat mengaharapkan respon balik demi kebaikan bersama agar bisa menemukan solusi masalah penyimpanan protokol notaris di kantor MPD.

Senada dengan Notaris Siti Noer Endah yang juga sebagai Ketua MPD Kota Malang periode 2015-2018 dan juga pemegang protokol Notaris lain, Notaris Yudi Ansyah sebagai anggota MPD Kota Malang periode 2015-2018, Notaris Dyah Ayu, Notaris Diah Widhiawati yang juga sebagai pemegang protokol Notaris lain (Notaris Darma Sanjata Sudagung), Notaris Ita Kristiana yang juga sebagai pemegang protokol Notaris lain (Notaris Eko Handoko), Notaris Sulasiyah Amini dan Notaris Faisal Abdullah Waber bahwa pelaksanaan Pasal 63 ayat 5 UUJN tidak dijalankan alias tidak efektif, maka demikian juga dengan pelaksanaan Pasal 70 huruf e UUJN otomatis juga tidak dijalankan karena saling terkait antara keduanya, sehingga bisa disimpulkan bahwa tempat untuk menyimpan protokol Notaris yang sudah berusia seperempat abad atau lebih tidak berjalan efektif.

Penelitian terhadap efektifitas suatu aturan hukum adalah penting dalam kaitannya untuk mengetahui tentang bagaimana bekerjanya aturan hukum tersebut dalam praktek serta memastikan bahwa aturan itu adalah efektif atau tidak. Dengan demikian dapat dipastikan pula perlu tidaknya diadakan suatu perbaikan atau penyempurnaan, antara lain berupa pencabutan atau penambahan dan sebagainya. ${ }^{7}$ Terkait dengan hasil penelitian mengenai efektifitas tempat penyimpanan prtotokol notaris yang berumur 25 (dua puluh lima) tahun yang tidak berjalan efektif maka perlu

${ }^{7}$ M. Kafrawi, Efektifitas Pasal-pasal KUHP yang Berkenaan dengan Pelaksanaan Program KB Nasional di Jawa Timur,Disertasi, (Surabaya: Universitas Airlangga, 1989), hal. 55 
segera dicari faktor-faktor penyebabnya sekaligus solusi pemecahannya, agar bisa segera diambil tindakan mengenai langkah-langkah perbaikan atau penyempurnaan atau bahkan pencabutan pasal tersebut dari UUJN sehingga tidak merugikan bagi notaris penyimpan protokol dan masyarakat atau penghadap dan ahli warisnya. Dalam hal ini aturan tersebut tidak bisa berjalan efektif karena faktor sarana atau fasilitas yang kurang mendukung dalam penegakan hukum, dalam hal ini gedung dan fasilitas lain tidak menunjang atau kurang representatif.

Hal ini apabila dihubungkan dengan teori kewenangan terkait dengan penelitian dalam tesis ini, mengenai efektifitas tempat penyimpanan protokol notaris yangsudah berusia seperempat abad jo. Pasal 70 huruf e UUJN maka penentuan tempat untuk menyimpan protokolNotaris merupakan salah satu kewenangan dari MPD yang harus dijalankan. Selama ini tidak dijalankan harus dicari kendalanya apa dan segera dicari solusi pemecahannya. Karena dalam hal ini MPD merupakan kepanjangan tangan dari Menteri Hukum dan HAM maka MPD seharusnya meminta fasilitas gedung dan biaya operasional untuk pelayanan dan pengawasan Notaris dari Kementrian Hukum dan HAM. Sebenarnya apabila mengacu pada PerMenKum dan HAM No. 40/2015 tentang Majelis Pengawas pada Pasal 18 ayat (5) menjelaskan bahwa kantor sekretariat untuk MPDadalah di kantor UPT Kemenkum dan HAM atau di ibu kota kabupaten/kotamadya yang akan ditetapkan bersama berdasarkan rapat anggota MPD. Akan tetapi menurut Yudi Ansyah kondisi ruangan yang telah disediakan di kantor UPT Kementrian Hukum dan HAM tersebut terlalu kecil dan kurang representatif. Sedangkan untuk biaya operasional yang didapatkan dari Kementrian Hukum dan HAM ada namun tidak mencukupi untuk menunjang kelancaran kegiatan operasional MPD di kota Malang.

\section{Faktor penyebab tidak efektifnya tempat menyimpan protokolnotaris sudah berusia dua puluh lima tahun dan upaya penyelesaiannya}

\section{Faktor Aturan UUJN/UUJN-P}

Notaris Siti Noer Endah yang juga sebagai Ketua MPD Kota Malang periode 2015-2018 berpendapat bahwa pasal 57 UUJN menyebabkan pelaksanaan dalam menyimpan protokol yang sudah berusia seperempat abad atau bahkan lebih menjadi ribet/merepotkan bagi notaris, karena adanya aturan di UUJN pasal 57 yang isinya bisa disimpulkan sebagai berikut:bahwa yang dapat mengeluarkan Kutipan Akta, Salinan, Grosse Akta, atau pengesahan surat dibawah tangan yang dilekatkan pada akta yang tersimpan dalam protokol Notaris hanyalah Notaris yang membuatnya, Notaris pengganti, atau pemegang protokol notaris yang sah. 
Hal ini tentu akan merepotkan MPD dan Notarisnya bila protokol yang sudah berumur 25 (dua puluh lima) tahun atau lebih tersebut disimpan di kantor MPD. Maka penyimpanan di kantor notaris atau kantor notaris pemegang protokol akan lebih memudahkan bagi penghadap atau ahli waris penghadap yang membutuhkan protokol notaris yang telah lama tersebut. Selain itu juga belum diaturnya secara tegas batas waktu penyimpanan di dalam UUJN/UUJN-P dan masa kadaluarsanya atau Jadwal Retensi Arsip (JRA) yang menyebabkan penyimpanan protokol notaris semakin lama semakin merepotkan bagi notaris, notaris penyimpan/pemegang protokol notaris lain dan tentunya bagi MPD.

Senada dengan pendapat Notaris Siti Noer Endah, Notaris Yudi Ansyah juga mengatakan bahwa faktor penyebab protokol notaris berumur 25 tahun tidak diserahkan ke MPD adalah karena MPD tidak mempunyai kantor sendiri atau menumpang di kantor Ketua MPD. Maka salah satu solusinya adalah MPD membuat kantor yang bisa memuat seluruh protokol yang minimal sudah berusia seperempat abad, dan sudah waktunya untuk membuat aturan baru yang jelas mengenai jangka waktu penyimpanan dan masa kadaluarsa protokol notaris.

Sedangkan Notaris Dyah Widhiawati, berpendapat sama bahwa karena MPD tidak punya kantor, solusinya adalah bahwa MPD harus segera punya kantor sendiri yang bisa menampung protokol yang minimal sudah berusia seperempat abad agar lebih tertib dalam administrasi penyimpan penyimpanannya. Notaris Ita Kristiana,berpendapat sama bahwa karena MPD tidak punya kantor maka solusinya harus punya kantor sendiri. Notaris senior di Kota Malang yaitu Faisal Abdullah Waberpun berpendapat bahwa karena MPD tidak punya kantor dan terlalu merepotkan Notaris yang harus selalu memonitor arsip-arsip yang sudah berusia dua puluh lima tahun atau lebih. Solusinya menurut beliau yaituMPD harus punya kantor yang bisa menampung protokol-protokol notaris yang seharusnya disimpan di kantor MPD yaitu protokolnotaris yang minimal sudah berusia minimal seperempat abad, solusinya MPD harus mendapatkan dana operasional dan gedung yang representatif dari Kementrian Hukum Dan Hak Asasi Manusia. Pendapat dari Notaris Sulasiyah Amini intinya sama dengan pendapat notaris-notaris yang telah saya sebutkan di atas bahwa faktor penyebabnya karena MPD tidak punya kantor yang representatif, sedangkan solusinya menurut beliau adalah bahwa MPD harus punya kantor sendiri yang besar yang bisa menampung protokol notaris yang minimal sudah berusia seperempat abad sesuai dengan amanat Pasal 70 huruf e UUJN.

Di dalam Undang-Undang Nomor 43 Tahun 2009 Tentang Kearsipan ada pasal-pasal tentang arsip yang telah habis masa retensinya bisa dimusnahkan (pasal 49 huruf b), sedangkan di UUJN/UUJN-P 
mengenai Jadwal Retensi Arsip belum diatur secara tegas, sehingga waktunya tidak terbatas dalam arti arsip harus disimpan selamanya. Akan tetapi jika menggunakan dasar KUH Perdata dan KUH Pidana maka bisa dipakai batasan kadaluarwarsa tersebut pada pasal 1967 yang isinya bahwa semua tuntutan hukum, baik yang bersifat kebendaan maupun yang bersifat perorangan, hapus karena lewat waktu dengan lewatnya waktu tiga puluh tahun, sedangkan orang yang menunjukkan suatu atas hak, dan terhadapnya tak dapat diajukan suatu tangkisan yang didasarkan pada itikad buruk. Hal ini bisa dipakai batas waktu 30 tahun untuk menyatakan batas kadaluawarsanya. Sedangkan untuk masalah yang termasuk unsur pidana bisa dipakai batasan masa kadaluwarsa sampai 12 tahun yang terdapat pada pasal 78 KUH Pidana.

.Di dalam Pasal 65 UU Republik Indonesia No.30 tahun 2004 tentang Jabatan Notaris (UUJN) yang berbunyi bahwa Notaris, Notaris Pengganti, dan Pejabat Sementara Notaris bertanggungjawab atas setiap Akta yang dibuatnyameskipun Protokol Notaris telah diserahkan atau dipindahkan kepada pihakpenyimpan Protokol Notaris. Dengan dasar pasal tersebut di atas maka dapat disimpulkan bahwa protokolnotaris tersebut meskipun sudah dipindahtangankanpenyimpananya kepada pihak penyimpan protokol maka harus tetap disimpan, dijaga dan dirawat keasliannya. Namundalam hal ini mengingat protokol notaris dipandang sebagai sebuah arsip penting negara maka haruslahmemiliki dasar hukum atau aturan baku untuk pengelolaan/perawatannya, terutama jika terkait dengan kurun waktumenyimpan yang dikenal dengan istilah retensi arsip.

Adanya suatu kepastian hukum, yaitu agar supaya masyarakat mengerti akan adanya kepastian tentang apa yang boleh dilakukan dan apa yang tidak boleh dilakukan oleh anggota masyarakat. ${ }^{8}$ Dari teori kepastian hukumtersebut dapat ditarik menjadi dua pengertian sebagai berikut: a) Adasuatu aturan dimana individu bisa tahu dan paham bahwa ada perbuatan yang boleh dan yang tidak boleh dilakukan; b) Ada keamanan hukum, yaitu berupa jaminan kepastian hukum bagi setiap warga dari kesewenangwenangan pelaksana negara sehingga warga negara mengetahui apa yang boleh negara lakukan terhadap warganya. ${ }^{9}$ Tanpa adanya kepastian hukum tentu akan menimbulkan keresahan dalam masyarakat, dan akan menimbulkan ketidakpercayaan masyarakat pada pemerintah.

Berkaitan dengan penelitian dalam tesis ini teori kepastian hukum untuk menjawab permasalahan tentang tidak efektifnya tempat

${ }^{8}$ Wirjono Prodjodikoro,Perbuatan Melanggar Hukum Dipandang Dari Sudut Hukum Perdata, (Bandung: Mandar Maju, 2000), hal. 11.

${ }^{9}$ Peter Mahmud Marzuki, PengantarIlmu Hukum, (Jakarta: Kencana Predana Media Group, 2008), hal. 158. 
menyimpanprotokol Notaris yang sudah berusia minimal seperempat abad terkait faktor penyebabnya yaitu faktor aturan hukum, dimana di dalam UUJN tidak diatur dengan jelas mengenai Jadwal Retensi Arsip yang menyebabkan protokol Notaris tersimpan selamanya dan menumpuk begitu banyak, dan jika protokol yang telah berusia dua puluh lima tahun atau lebih tersebut disimpan di kantor Notari maka akan merepotkan karena semakin lama tentunya akan semakin banyak dan tentunya akan menimbulkan masalah dalam hal penyimpanan. Untuk menjamin protokol Notaris sebagai suatu alat bukti otentik dari suatu perbuatan hukum masyarakat yang bisa memberikan suatu kepastian hukum, maka pejabat notaris, notaris pengganti, pemegang protokol notaris lain dan Majelis Pengawas Daerah Notaris harus menjaga dan merawat protokol Notaris tersebut.

.Menurut I Pasal 1 ayat (22) UU Nomor 43 Tahun 2009 tentang Kearsipan, dapat disimpulkan bahwa Jadwal Retensi Arsip (JRA) adalah daftar kurun waktu dalam menyimpan atauretensi, jenis dari arsip, dan keterangan catatan/usulan tentang menetapkan suatu jenis arsip apa akan dimusnahkan, dinilai kembali, atau akan dipermanenkan dipergunakan untuk pedoman dalam hal menetapkan nilai penyusutan dan menyelamatkandokumen/arsip. Menurut Peraturan Pemerintah Nomor 28 tahun 2012 yang dikeluarkan sebagai pedoman aturan pelaksanaan UndangUndang Kearsipan pada Pasal 1 ayat (37), dijelaskan tentang apa yang dimaksud dengan Retensi Arsip, yaitu kurun waktu atau lamanya di dalam menyimpan suatu dokumen/arsip yang harus dilaksanakan pada jenis dokumen/arsiptertentu.

\section{Faktor Tempat Penyimpanan}

Faktor tempat atau gedung sangatlah urgent untuk dapat melaksanakan Pasal 63 ayat (5) UUJN/UUJN-P yang sangat berkaitan dengan pelaksanaan Pasal 70 huruf e UUJN, dimana pada kenyataannya banyak kantor-kantor MPD yang belum mempunyai gedung sendiri. Jika dikaitkan dengan teori kepastian hukum dan teori tanggungjawab maka dalam tesis ini maka untuk memberikan kepastian hukum bagi penghadap dengan adanya tempat/gedung yang representatif yang bisa menampung protokol-protokol Notaris yang sudah waktunya diserahkan ke MPD akan menjamin kepastian hukum karena arsip-arsip tersebut tentunya lebih terjamin dari resiko hilang dan kerusakan. Karena seperti kita ketahui bersamabahwa MPD ini dibentuk oleh Kemenkum HAM RI maka sudah sepantasnya bila memiliki gedung tersendiri yang memadai dan diberi dana operasional yang cukup untuk menunjang tugas-tugas MPD yang begitu penting di dalam pengawasan kinerja Notaris di daerah dan melindungi arsip/protokol notaris yang juga merupakan arsip negara. Salah satu kendala 
tersebut disebabkan karena penyimpanan protokol-protokol notaris tersebut membutuhkan tempat yang luas dan memadai untuk tempat penyimpanan mengingat pentingnya menyimpan protokol-protokol notaris tersebut dalam jangka waktu yang lama dan belum ditentukan batas kadaluarsanya di UUJN/UUJN-P. Sehingga membutuhkan tempat yang memenuhi standar yang layak sebagai tempat penyimpanan arsip, dan butuh pengawasan yang intensif agar tidak cepat rusak dimakan jaman/cuaca/kelembaban atau serangga/rayap.

Jika dikaitkan dengan teori kewenangan maka MPD harus melaksanakan kewenangannya yang sudah ditetapkan Undang-Undang dengan segera memiliki gedung sendiri agar bisa melaksanakan ketetapan Undang-Undang dengan baik yang akhirnya bisa menjamin kepastian hukum bagi penghadap atau ahli waris notaris yang suatu saat membutuhkan arsip-arsip tersebut.

Solusinya MPD harus segera mempunyai gedung sendiri yang representatif sehingga bisa menampung seluruh protokol notaris yang mimimal sudah berusia seperempat abad seperti pendapat sebagian besar responden, juga perlu dibuatkan aturan baru yang lebih jelas mengenai aturan kadaluarsa akta atau protokol notaris di dalam UUJN/UUJN-P, sehingga protokol-protokol notaris atau akta yang sudah lama dan nilai kemanfaatannya sudah berkurang atau sudah tidak bernilai secara hukum bisa dimusnahkan. Atau perlu dibuatkan aturan baru tentang cara penyimpanan yang lebih modern atau dalam bentuk media elektronik/digital sehingga tidak banyak memerlukan tempat, yang tentunya perlu perubahan atau penambahan aturan di dalam UUJN/UUJN-P.

\section{KESIMPULAN}

Penyimpanan protokol notaris yang telah berumur 25 tahun jo. Pasal 70 huruf e UUJN untuk saat ini tidak dijalankan atau tidak efektif karena terbentur masalah tidak adanya tempat penyimpanan dikarenakan MPD belum mempunyai gedung sendiri dan kurangnya dana operasional. Faktorfaktor yang mempengaruhi efektivitas penyimpanan protokol notaris adalah yang pertama masalah aturan yang ada di UUJN dimana belum ditentukan secara tegas mengenai Jadwal Retensi Arsip dan yang kedua adalah masalah tempat penyimpanan, dimana MPD belum mempunyai gedung sendiri. Solusinya adalah MPD harus mempunyai gedung sendiri yang representatif untuk menyimpan dokumen-dokumen penting milik notariss yanng sudah berusia minimal seperempat abad, dan perlu dibuatkan aturan baru yang jelas tentang masa kadaluarsa dari akta/protokol notaris yang sudah tidak bernilai secara hukum atau nilai kemanfaatannya sudah berkurang di UUJN/UUJN-P. Sedangkan untuk tempat penyimpanan perlu dibuatkan 
aturan baru mengenai penyimpanan yang lebih modern dan tidak banyak memerlukan tempat dengan menggunakan penyimpanan dalam media elektronik/digital.

\section{DAFTAR PUSTAKA}

Abdulkadir Muhammad, 2004, Hukum dan Penelitian Hukum, Bandung: Citra Aditya Bakti.

Agus Salim Andi Gadjong, 2007, Pemerintahan daerah kajian Politik Hukum, Bogor: Ghalia Indonesia.

Koentjaraningrat, 1993, Metode-metode Penelitian Masyarakat, Jakarta: PT. Gramedia Pustaka Utama.

M. Kafrawi, 1989, Efektifitas Pasal-pasal KUHP yang Berkenaan dengan Pelaksanaan Program KB Nasional di Jawa Timur,Disertasi, Surabaya: Universitas Airlangga.

Peter Mahmud Marzuki, 2008, PengantarIlmuHukum, Jakarta: Kencana Predana MediaGrouup.

Sukandarrumidi, 2006, Metode Penelitian: Petunjuk Praktis untuk Penelitian Pemula, Yogyakarta: Gajah Mada University Press.

Suratman dan Philips Dillah, 2015, Metode penelitian Hukum, Bandung: Alfabeta.

Wirjono Prodjodikoro, 2000, Perbuatan Melanggar Hukum Dipandang Dari Sudut Hukum Perdata, Bandung: Mandar Maju.

\section{Undang-Undang}

Undang UndangRepublikIndonesia No.30/2004 tentang Jabatan Notaris, Yogyakarta: Pustaka Mahardika.

Undang UndangRepublik Indonesia No.2/2014 tentang Perubahan Atas Undang Undang Republik Indonesia No.30/2004 tentang Jabatan Notaris, Yogyakarta: Pustaka Mahardika. 